\title{
Namibiese bosoorlog uit die pen van deurwinterde krygshistorikus
}

Cas Bakkes, Boskroniek (April - Junie 1977): Dagverbaal van'n Grenssoldaat (Pretoria: C.M. Bakkes (Solana nr.5, Clublaan 97, Waterkloofhoogte, 0181, Tel./Faks: 012 347-8604), 2008). Pp. ix + 307; Woordelys, register, foto's, illustrasies, uitvoukaart.

ISBN 978-0-620-41232-2

R250,00 (posgeld ingesluit)

Suid-Afrika se omstrede 'Bosoorlog' in Noord-Namibië en Suid-Angola (1966 - 1989) is twee dekades na sy voltrekking steeds ' $n$ aktuele onderwerp wat hewige debat uitlok en telkens skrywers na die pen laat reik om die 'waarheid' te ontbloot. Verskeie van dié, dikwels outobiografiese, werke streef in die tradisie van John Keegan se bekende The Face of Battle $e^{1}$ daarna om grepe uit dié oorlog aan die leserspubliek oor te dra soos die soldaat op die grond dit regtig beleef het. Een so 'n werk is Louis Bothma, 'n voormalige dienspligoffisier, se besonder geslaagde boek oor 32 Bataljon" wat trag om die lede van dié elite eenheid se ervaring van die Bosoorlog en ook hul naoorlogse ontgogeling met die politieke owerheid van die dag weer te gee. Bothma se boek is, in sy eie woorde, veral bedoel vir 'dié mense wat nooit die Grensoorlog gesien en verstaan het nie; vir ons ouers, vrouens en kinders - vir almal wat... die waarheid oor daardie oorlog wil hoor... hoe dit was - daardie jare toe seuns manne moes wees... hoe politici met mense in 'n oorlog kan mors... wie ons was... wat in die bos gebeur het...'. van begrippe in die neo-klassieke ekonomie waar deterministiese metingsinstrumente ontwikkel is om die administrasie en bestuur van owerheidsienste verstaanbaar te maak. Die gekombineerde gebruik van kennis, tussen die dissiplines van ekonomie, rekeningkunde, owerheidsadministrasie en moderne ingenieurswese het hierdie innovasies genoodsaak. ${ }^{3}$

In sy Boskroniek wil Bakkes insgelyks die leser saamneem na die operasionele gebied om die sleur, ontbering en sporadiese momente van hoogspanning van die lae-intensiteit bosoorlog mee te maak soos die gewone manskap dit werklik ervaar het. Hy wil egter terselfdertyd ook gestalte gee aan sy diepe teleurstelling oor die politieke 'kapitulasie' van die vroeë negentigerjare. As deurwinterde krygshistorikus ${ }^{4}$ 'laat' hy dus sy boek 'na as 'n bron... vir die militêre historiograaf wat... die grensstryd

1. John Keegan, The Face of Battle (Jonathan Cape: London, 1976 \& Penguin: London, 1978).

2. L.J. Bothma, Die Buffel Struikel: 'n Storie van 32 Bataljon en sy Mense (L.J. Bothma: Bloemfontein, 2006).

3. L.J. Bothma, Die Buffel Struikel, pp. 5-6.

4. Bakkes was van 1954 tot 1968 'n dosent in Krygsgeskiedenis aan die Militêre Akademie, waarna hy Direkteur 
sal navors en ontrafel' en 'dra die inhoud op aan my strydmakkers en ons nageslagte om die gebeure te beleef soos dit vir ons voor die oë van God afgespeel het' (p. 8). Maar as stoere Afrikanernasionalis binne sy bepaalde denkskool laat hy sy werk ook na as 'n bron 'opdat ons nie vergeet nie en diegene wat na ons kom ons van die skande wat halfhartige en wankelmoedige bewindhebbers oor ons verlede en toekoms gebring het, kan reinig' (p. 278). Met 'n familiegeskiedenis wat die letsels van die AngloBoereoorlog en die Britse konsentrasiekampe dra, skryf hy, 'weet ek en my mense baie... van verdrukking deur vreemde oorheersing' (pp. 1-2). Van sy voorouers het hy geleer hoe sy 'prioriteit ten opsigte van die mensheid moet lê, verloop en moet wees, naamlik "Eie Volk Eerste!” (p. 2).

Boskroniek is die verwoording van die vergestalting van ' $n$ 'militêre droom' waarmee Bakkes reeds as ' $n$ jong seun 'besiel [was] as gevolg van die naweë van die [Anglo-Boere] oorloë, Rebellie en staking [1922] waarin ek groot word' (p. 4). As tienderjarige was hy met die uitbreek van die Tweede Wêreldoorlog 'baie gretig' om sy '(militêre) droom te verwesenlik' en het hy by die Ossewa-Brandwag se ondergrondse militante vleuel, die Stormjaers, aangesluit om 'as jong ondergrondse stryder... [sy] gewig teen die geallieerdes (in te gooi)' (p. 1), 'vasberade dat die Britse Union Jack neergehaal word', maar terselfdertyd ook vasberade dat ' $n$ 'Republiek geproklameer word voordat die Duitse Hakekruis in die Union Jack se plek oor Suid-Afrika begin wapper' (p. 4). Met die Duitse oorgawe in 1945 het hy hom 'aan die verloorkant... bevind' en was, in sy woorde, 'ons republiekwording nie militêr verwesentlik soos ek begeer het nie, maar my militêre droom bly nog steeds brandend soos toe dit in my kindergemoed ontwaak het' (p. 5).

Bakkes het ná die Tweede Wêreldoorlog as vrywilliger eers by die Aktiewe Burgermag en kort daarna, as dosent in Krygsgeskiedenis aan die Militêre Akademie, by die SA Staande Mag aangesluit om sy lankgekoesterde 'militêre droom' uit te lewe. In navolging van dié droom het Bakkes begeer om aktief betrokke te raak by die teeninsurgensiestryd, die 'Bosoorlog', waarin die RSA sedert 1966 in NoordNamibië gewikkel was en so deel te word van wat hy beskou het as die voortgesette vryheidstryd van die Afrikaner. Sy droom het in vervulling gegaan toe daar teen 1977 enersyds openbare kritiek was dat 'jong seuns [militêre dienspligtiges] in die grensgebied... die spit moet gaan afbyt, terwyl die ouer offisiere relatief veilig... buite gevaarsones die gevegsbeplanning doen', en daar andersyds 'n behoefte ontstaan het om 'die bestaande offisierskorps se gevegservaring vinniger uit te brei na ' $n$ breër spektrum veral van die Burgermag en die Kommando’s... [en] ook die Staande Mag... as gevolg van die steeds naderkruipende terreuroorlog na die Suid-Afrikaanse binneland...' (p. 7). Sodanige offisiere is die geleentheid gebied om vrywillig as gewone manskappe grensdiens te verrig. Bakkes, toe ' $n$ kommandant in die Burgermag en op 52-jarige leeftyd ' $n$ toonbeeld van liggaamlike fiksheid, het hierdie geleentheid met beide hande aangegryp en hom gretig as gewone voetsoldaat in leefwêreld van die grensvegter begewe.

Bakkes se werk verskil veral in twee opsigte van die meeste ander werke wat die afgelope paar jaar oor die Bosoorlog verskyn het. Eerstens handel dit nie oor die hoogtepunt van die oorlog nie, maar speel dit af in die tydperk April tot Junie 1977 voordat Suid-Afrika se teeninsurgensie-operasies in opvolg-, hakkejag en voorsprongoperasies oor die Angolese grens heen geëskaleer het. Tweedens is dit nie ' $n$ boek in die konvensionele sin van die woord nie, maar ' $n$ greep uit sy dagboek wat hy reeds sedert 1942 byhou. Dit is egter ook nie ' $n$ konvensionele dagboek nie. Hy bied sy 'dagverhaal' aan in die vorm van 'n 'dagbrief' aan sy vrou, aangevul deur korter briewe wat hy tydens sy 'bostoer' aan haar, sy vier kinders, sy moeder en ander familielede, asook vriende en kollegas geskryf het. 
Die boek beslaan twintig kort hoofstukke en word afgesluit met ' $\mathrm{n}$ aanhangsel waarin hy ' $\mathrm{n}$ bondige evaluasie maak van die bydrae wat sy kompanie tydens hul 'bostoer' tot die grensoorlog gelewer het. Hoofstuk I word voorafgegaan deur ' $\mathrm{n}$ vyftal bedankingsbriewe aan persone wat sy manuskrip beoordeel en hom andersins met die versorging van sy werk behulpsaam was. Hoofstuk I bestaan uit 'n outobiografiese skets wat sy jeug, loopbaan en lewensfilosofie in enkele paragrawe saamvat en die aanloop tot sy grensdiens verduidelik.

Hoofstukke II tot $\mathrm{X}$ behandel die mobilisasie van die militêre eenheid waarin hy saam met ' $\mathrm{n}$ mengelmoes van kommando, Burgermag- en Staandemagoffisiere opgeneem is, naamlik die (Danie Theron) Krygskoolkompanie, asook hul verskuiwing vanaf Kimberly na Oshivello in Namibië en hul opleiding in daardie omgewing. Dié opleiding, waartydens hulle 'soos gewone troepe... gedril, gedryf en gejaag' (p. 111) is, was vir Bakkes louter vreugde. Hy skryf in dié verband: 'Meteens oorstelp 'n grote dankbaarheid my. Ek sluit my oë en ek praat met God en dank Hom vir die groot "Geskenk" aan my - die geleentheid om weer aan 'n Oorlog te mag deelneem' (p. 26). En verder: 'Om so fiks, gesond en blymoedig te wees, is weelde. Onder sulke omstandighede is die Duitse spreuk: "Es gibt kein schöneres Leben als das Soldatenleben" onteenseglik waar' (p. 67).

Hoofstukke XI tot XVII vorm die hoofelement van Bakkes se verhaal. Dit beskryf naamlik die operasionele ontplooiing van die Krygskoolkompanie in die Oshigambo-area en sy wederervaringe as gewone manskap tydens patrollies, vee-operasies, padblokkades en (nagtelike) hinderlae. Hy beskryf haas elke tree wat hy en sy makkers gee, elke handeling wat hulle uitvoer, die terrein, plantegroei, klimaat, asook die plaaslike bevolking en hul leefwyse. Die plaaslike bevolking in Ovamboland was deurgaans sterk SWAPO-gesind. Bakkes en sy kamerade het derhalwe met die oog daarop om steun te werf en op 'subtiele wyse' inligting in te win' (p. 141) dikwels besoeke aan krale en dorpies gebring, gesprekke met hoofmanne gevoer, leeus geskiet wat hul beeste gevang het en soms self elementêre mediese hulp verleen. Almal was egter nie ontvanklik vir hul pogings nie. Hy skryf: 'Ons kom by 'n beeskraal. Daar is 'n ou madala en twee klonkies met stertriempies. Ek probeer aan laasgenoemde elk ' $n$ soldatebeskuitjie gee. Hulle weier die aanvaarding konsekwent. "Hardegatjies!" dink ek en steek verleë my beskuitjies in my dysak' (p. 146).

Bakkes lewer deurlopende kommentaar op elkeen wat hy teëkom - van sy kamerade, hul Flechaspoorsnyer en Ovambo-tolk, tot die bevelselement in die operasionele gebied in Ovamboland (2 Militêre Gebied), laasgenoemde feitlik almal sy oudstudente aan die Militêre Akademie. Hy skets hul uniekhede en besing hul persoonlike deugde, maar spreek ook soms kritiek uit op hul tekortkominge. Sy beskrywing is deurgaans eerlik, grafies en filosofies, maar terselfdertyd ook fyn prosa. ${ }^{5} \mathrm{Hy}$ slaag goed daarin om die leser self te laat ervaar wat hy beleef het. So skryf hy onder meer 'dit is nou baie warm en ons plof aan deur baie dik, los (wit) sand. Ons sweet... ons stap lui en stadig... (ons) dra swaar... Eindeloos strek die sandkaplyn oor Afrika na die son' (p. 146). Onder hierdie omstandighede probeer Bakkes aan sy minder geesdriftige makkers deurgaans 'die boodskap oordra dat indien ons die ding hier in die wildernis wil doen, ons onversaag en eindeloos moet wees. Ons moet onverslytbaar, onvermurfbaar, onbreekbaar, dag na dag, ondanks son en sand, in die woestyn aanwesig bly en ons laat geld' (p. 146).

5. Op p. v haal hy vir Kobie Gouws aan wat opgemerk het dat sy dagboek "stuk-stuk letterkunde (bevat) Afrikaans wat die leser diep in die hart gryp... al sou hierdie dagboek dan kwansuis nie meer "historiese relevansie' bevat nie, sal sy kulturele en letterkundige waarde 'n publikasie regverdig!". 
As besielde 'grensvegter' het Bakkes elke oomblik vurig na die geveg uitgesien. Helaas het sy kompanie uiteindelik net by twee geleenthede 'kruit geruik'. By die eerste geleentheid, ' $n$ landmyninsident op 1 Junie 1977, was hy self betrokke. Dié ervaring beskryf hy met die waarnemersoog van die historikus en die pen van die prosakunstenaar in fyn, meevoerende detail (pp. 148-149, 151):

Ons ry. Die ou monster ["Spook" - gepantserde troepedraer] kry swaar. Derrek gooi hom in vier-wiel-rat en toe gebeur dit! Dit is ineens - so onwerklik! Staal skeur soos papier. Daar's 'n knal en iets knars soos die hou wat uit die nag op die harnas val van die jong paladyn in die verhaal "Drogon” van Arthur van Schendel. Meteens vul rook en stof die binneruim en die makkers om my vervaag. My geweer ruk los uit sy staanrak en val tussen die raamwerk van my bankie in... Die Browning-masjiengewere in die luik op die dak knak en 'n goue waterval van blink patrone en patroonbande stort in Terrence se leë sitplek... Oor alles syfer ' $n$ vaalwit as uit die lug... die bos om ons (is) aan die brand... Saam met die swael en wit poeierrook borrel ons deur die agterste luik... Die verdwaasdheid begin lig. Ons stemme raak los. Dis waaragtig waar. Ons het kruit geruik. Ons is almal behoue... Ons buig ons hoofde en ek bid. Ons sê diep dankbaar "Dankie". As ons van ons knieë opstaan hoor ek iemand sê: "Nou sal ons die Dônners skiet!".

Die Krygskoolkompanie se tweede kennismaking met die vyand was presies die soort kontak waarvan Bakkes gedroom het, maar wat sy seksie tot die end ontwyk het. Hy moes maar tevrede wees om te hoor hoe sy krygsgenote van Seksie 2, Peleton 3 kortstondig vuur met 'n groep 'Swapo-terroriste' wissel. Drie Swapo-vegters het in dié skermutseling gesneuwel, sonder enige ongevalle aan die kant van Seksie 2. Bakkes het die besonderhede van dié geveg haarfyn by die betrokkenes verneem, opgeteken en met 'n sketskaart en foto's toegelig (pp. 203-212).

Hoofstukke XVIII en XIX beskryf die Krygskoolkompanie se onttrekking aan die operasionele gebied en hul terugkeer na die RSA. In Hoofstuk XX, sy bondige 'Nawoord', spreek Bakkes sy bittere ontgogeling met die politieke leiers van sy tyd en die wyse waarop hulle die interne revolusionêre stryd in Suid-Afrika voltrek het, uit. Hy skryf onder meer:

Allengs moes ons wat ons lewens op die spel geplaas het, ontdek dat die bewind wat ons gedink het pal staan en van wie ons die opdrag had om te velde te gaan, besig was om agteraf polities gemene saak met die vyand te maak en... hulle rug te draai op ' $n$ volk se duur verworwe soewereiniteit; hulle persoonlike belange voorop te stel; op verskillende vlakke silwerlinge te aanvaar in die naam van vrede; die volk wat hulle eens sogenaamd gedien het se selfrespek te verdiskonteer; uiteindelik hul goedvertrouende volgelinge se politieke voertuig onder hulle uit te ontbind en bisar na die vyand oor te loop... sonder dat 'n enkele wapensukses te velde deur die terreurvegters teen die Suid-Afrikaanse magte aangeteken is... Deur die nuwe bewind van na '90 is ongevoelig, blatant en koelbloedig ' $n$ streep getrek deur die Afrikaner/Blanke se staatkundige selfbeskikking (pp. 277-278). 
Bakkes se verhaal is dwarsdeur subjektief maar eerlik veranker in sy persoonlike leefwêreld as Afrikanernasionalis binne sy bepaalde denkskool, wat 'n sterk ideologiese stempel op sy werk afdruk. Dit sal kritici hom sekerlik ten laste lê. Wat my betref, lê die waarde van sy werk veral op twee vlakke: eerstens, verwerklik sy besondere verteltrant in ryk prosa die vervelige, Spartaanse, geroetineerde, stof- en sweetdeurdrenkte bestaan van die grenssoldaat, wat kontradiktories in ' $n$ oogwink in ' $n$ inferno van rook, vuur en bloed kon uitbars, op 'n konkreet-beleefbare wyse vir die leser; en, tweedens, bied sy boek die leser 'n helder insig in die wyse waarop 'n bepaalde deel van veral die Afrikaner-sektor van Suid-Afrika se wit bevolking die teeninsurgensiestryd beleef het en hoe 'n gedeelte van hulle vandag die politieke koerswending van die negentigerjare onthou en beleef. Dit is beide as Afrikaanse prosa en as getinte lens op die verlede 'n waardevolle, uiters leesbare bydrae tot die lektuur van die Grensoorlog.

Deon Visser

Fakulteit Krygskunde (Militêre Akademie), Universiteit Stellenbosch 